University of Nebraska - Lincoln

DigitalCommons@University of Nebraska - Lincoln

USDA Wildlife Services - Staff Publications

U.S. Department of Agriculture: Animal and Plant Health Inspection Service

2013

\title{
Immunization with a Synthetic Peptide Vaccine Fails to Protect Mule Deer (Odocoileus hemionus) from Chronic Wasting Disease
}

John L. Pilon

United States Department of Agriculture (USDA), Animal and Plant Health Inspection Service (APHIS)

Jack C. Rhyan

USDA, APHIS, Veterinary Services

Lisa L. Wolfe

Colorado Division of Parks and Wildlife

Tracy R. Davis

Colorado Division of Parks and Wildlife

Matt P. McCollum

USDA, APHIS, Veterinary Services

See next page for additional authors

Follow this and additional works at: https://digitalcommons.unl.edu/icwdm_usdanwrc

Part of the Life Sciences Commons

Pilon, John L.; Rhyan, Jack C.; Wolfe, Lisa L.; Davis, Tracy R.; McCollum, Matt P.; O'Rourke, Katherine I.; Spraker, Terry R.; VerCauteren, Kurt C.; Miller, Michael W.; Gidlewski, Thomas; Nichols, Tracy A.; Miller, Lowell A.; and Nol, Pauline, "Immunization with a Synthetic Peptide Vaccine Fails to Protect Mule Deer (Odocoileus hemionus) from Chronic Wasting Disease" (2013). USDA Wildlife Services - Staff

Publications. 1557.

https://digitalcommons.unl.edu/icwdm_usdanwrc/1557

This Article is brought to you for free and open access by the U.S. Department of Agriculture: Animal and Plant Health Inspection Service at DigitalCommons@University of Nebraska - Lincoln. It has been accepted for inclusion in USDA Wildlife Services - Staff Publications by an authorized administrator of DigitalCommons@University of Nebraska - Lincoln. 


\section{Authors}

John L. Pilon, Jack C. Rhyan, Lisa L. Wolfe, Tracy R. Davis, Matt P. McCollum, Katherine I. O'Rourke, Terry R. Spraker, Kurt C. VerCauteren, Michael W. Miller, Thomas Gidlewski, Tracy A. Nichols, Lowell A. Miller, and Pauline Nol 


\title{
Immunization with a Synthetic Peptide Vaccine Fails to Protect Mule Deer (Odocoileus hemionus) from Chronic Wasting Disease
}

\begin{abstract}
John L. Pilon, ${ }^{1,7}$ Jack C. Rhyan, ${ }^{2}$ Lisa L. Wolfe, ${ }^{3}$ Tracy R. Davis, ${ }^{3}$ Matt P. McCollum, ${ }^{2}$ Katherine I. O'Rourke, ${ }^{4,6}$ Terry R. Spraker, ${ }^{5}$ Kurt C. VerCauteren, ${ }^{1}$ Michael W. Miller, ${ }^{3}$ Thomas Gidlewski, ${ }^{1}$ Tracy A. Nichols, ${ }^{1}$ Lowell A. Miller, ${ }^{1}$ and Pauline Nol $^{2,8}{ }^{1}$ United States Department of Agriculture (USDA), Animal and Plant Health Inspection Service (APHIS), Wildlife Services (WS), National Wildlife Research Center (NWRC), Fort Collins, Colorado 80521, USA; ' ${ }^{2}$ SDA, APHIS, Veterinary Services, NWRC, Fort Collins, Colorado 80521, USA; ${ }^{3}$ Colorado Division of Parks and Wildlife, Fort Collins, Colorado 80521, USA; ${ }^{4}$ USDA, Agricultural Research Service, Washington State University, Pullman, Washington 99164, USA; ${ }^{5}$ Department of Pathology and Microbiology, Colorado State University, Fort Collins, Colorado 80523, USA; 'Department of Veterinary Microbiology and Pathology, College of Veterinary Medicine, Washington State University, Pullman, Washington 99164, USA; 7 Current address: CETYA Therapeutics, Inc., 2512 Fox Run Court, Fort Collins, Colorado 80526, USA; ${ }^{8}$ Corresponding author (email: pauline.nol@aphis.usda.gov)
\end{abstract}

ABSTRACT: Chronic wasting disease (CWD) adversely affects both wild and captive cervid populations. A vaccine to prevent CWD would be a highly desirable tool to aid in disease management. To this end, we tested in mule deer a combination of CWD vaccines consisting of cervid prion peptide sequences 168-VDQYNNQNTFVHDC-182 and 145NDYEDRYYRENMYRYPNQ-164 that had previously been shown to delay onset of clinical disease and increase survival in a mouse-adapted scrapie model. Thirteen captive mule deer (Odocoileus hemionus) were divided into vaccine $(n=7)$ and control groups $(n=6)$, and given prime and boost vaccinations intramuscularly 5 wk apart. Eight weeks postprime (3 wk postboost), all animals were challenged via natural exposure to an environment contaminated with infective CWD prions. Deer were monitored intermittently for prion infection by rectal and tonsil biopsies beginning 275 days postchallenge. All vaccinates responded to both peptide conjugates present in the combination vaccine as measured by enzyme-linked immunosorbent assay. However, all deer eventually became infected regardless of vaccine status.

Key words: Cervid, chronic wasting disease, mule deer, prion, vaccine.

Chronic wasting disease (CWD), caused by infectious cervid prion $\left(\mathrm{PrP}^{\mathrm{CWD}}\right)$, affects several North American species, including mule deer (Odocoileus hemionus; Williams and Young, 1980). In western North America, the expansion of CWD coincided with population declines of up to $50 \%$ in some areas (Miller et al., 2008b). The captive deer industry also has been significantly impacted (Spraker et al., 2009). Both wildlife managers and com- mercial deer producers could benefit from a vaccine that prevents $\mathrm{PrP}^{\mathrm{CWD}}$ infection.

A previous vaccine study involving prion peptide sequences identified two conjugate sequences, peptides 4 and 6 , that induced a delay in clinical disease onset and prolonged survivorship in mice challenged with Rocky Mountain Laboratory mouse-adapted scrapie (Pilon et al., 2007). Here we describe a study in which mule deer were vaccinated with the cervid forms of peptides 4 and 6 and challenged via exposure to a $\mathrm{PrP}^{\mathrm{CWD}}$-contaminated environment. We assessed the combined vaccines' ability to prevent $\mathrm{PrP}^{\mathrm{CWD}}$ infection in this species.

Peptide 4 (168-VDQYNNQNTFVHDC-182) and peptide 6 (145- NDYEDRYYRENMYRYPNQ-164) were prepared as described by Pilon et al. (2007) with the exception of increased scale of conjugation and supplier of peptide (Midwest Bio-tech, Inc., Fishers, Indiana, USA). Peptides 4 and 6 were $85.7 \%$ identical (100\% similar) and $94.7 \%$ identical (100\% similar) to peptides 4 and 6 respectively in the mouse study. Peptide 6 was synthesized with a C-terminal linker containing a glycine and cysteine for sulfhydryl-mediated conjugation to blue carrier protein (BCP; Biosonda, Santiago, Chile). Peptide 4 was conjugated using the cysteine amino acid at the carboxyl terminus of the peptide. Both peptides were $>90 \%$ pure. Next, $22 \mu \mathrm{mol}$ of each peptide was conjugated separately to BCP 
using the linker reagent sulfosuccinimidyl 4 -( $N$-maleimidomethyl) cyclohexane-1carboxylate (Sulfo-SMCC, Pierce, Rockford, Illinois, USA). Peptide conjugates were dialyzed into $2 \mathrm{~L}$ phosphate-buffered saline (PBS) overnight using $10 \mathrm{~K}$ molecular weight cutoff dialysis membranes. Protein concentration was determined by bicinchoninic acid assay and formulated into an oil-in-water emulsion with mollusk stabilizing buffer (MSB) (30 mM phosphate; $400 \mathrm{mM} \mathrm{NaCl} ; 41 \mathrm{mM}$ sucrose; $\mathrm{pH}=7.4$ ) and an adjuvant (Adjuvac ${ }^{\mathrm{TM}}$; Miller et al., 2000). The final peptide conjugate concentration was $1 \mathrm{mg} / \mathrm{mL}$.

In November 2005, thirteen 6-monthold mule deer were acquired from a CWD-free research herd at Washington State University, Pullman, Washington, USA. Animals were transported to the United States Department of Agriculture (USDA) Animal and Plant Health Inspection Service (APHIS)/Animal Population Health Institute, Wildlife Research Facility, Colorado State University, Fort Collins, Colorado, USA.

In January, 2007 seven deer were vaccinated in each hip with $3 \mathrm{~mL}(1 \mathrm{mg} / \mathrm{mL})$ of each vaccine for a total of $6 \mathrm{mg}$ via intramuscular (IM) injection. A booster was administered $5 \mathrm{wk}$ postprime as described above. Six control deer were injected as described above using MSB. Three weeks postbooster animals were transferred to the Colorado Division of Parks and Wildlife (CDPW), Foothills Wildlife Research Facility, Fort Collins, Colorado, for natural challenge. Deer were placed in a 0.04-ha paddock that was contaminated with $\mathrm{PrP}^{\mathrm{CWD}}$ from previous CWD studies conducted on the premises (Miller et al., 2012). The study protocol was approved by the USDA APHIS National Wildlife Research Center and the CDPW institutional animal care and use committees (IACUC).

Prior to vaccination, EDTA whole blood was collected for genetic testing as described by Spraker et al. (2002). Serum was collected for analysis by enzymelinked immunosorbent assay (ELISA) before prime and booster, and at 3, 7, 9, 15 , and 21 mo postchallenge. For the ELISAs, peptides were conjugated to maleic anhydride plates (Thermo Scientific, Rockford, Illinois, USA) following manufacturer's instructions at $12.5 \mu \mathrm{g} / \mathrm{mL}$. Plates were blocked with SeaBlock (1:10) (Pierce). Serum was diluted in PBS and incubated $2 \mathrm{hr}$ at $37 \mathrm{C}$ covered with parafilm. Plates were washed twice with $200 \mu \mathrm{l}$ PBS containing $0.05 \%$ v/v tween-20, and incubated at $37 \mathrm{C}$ for $1 \mathrm{hr}$ with $200 \mu \mathrm{L}$ 1:500 goat-antideer IgG horseradish peroxidase-conjugated antibody (Kirkegaard and Perry Laboratories, Gaithersberg, Maryland, USA) diluted 1:2000 in PBS. Fifty microliters 3,3',5,5' -tetramethylbenzidine (Pierce) was added to wells, incubated at $37 \mathrm{C}$ for $5 \mathrm{~min}$, and quenched with $13 \mu \mathrm{L}$ of $2 \mathrm{M} \mathrm{H}_{2} \mathrm{SO}_{4}$. Plates were read at $450 \mathrm{~mm}$ (Opsys plate reader, Dynex Technologies, Chantilly, Virginia, USA).

Prior to prime vaccination, rectal biopsies were collected to determine CWD status (Wolfe et al., 2007); all animals were CWD free. At 9, 15, and 21 mo postchallenge, rectal and tonsillar biopsies (Wolfe et al., 2002) were collected under sedation using ketamine hydrochloride (Ketaset ${ }^{\circledR}$, Fort Dodge Animal Health, Fort Dodge, Iowa, USA; $7 \mathrm{mg} / \mathrm{kg}$ IM) and xylazine hydrochloride (AnaSed ${ }^{\circledR}$, Lloyd, Inc., Shenandoah, Iowa, USA; $0.7 \mathrm{mg} / \mathrm{kg}$ IM). Lymphoid tissues were collected from alternating tonsils and rectal lymphoid tissue collected from a new location each time. Tissues were fixed in $10 \%$ buffered formalin and prepared for histologic examination and immunohistochemistry as described by Spraker et al. (2006, 2009). Positive animals were defined as having positively staining follicles in rectal or tonsil tissue.

As animals became CWD positive on biopsy, they were anesthetized with tiletamine hydrochloride/zolazepam (Telazol ${ }^{\circledR}$, Fort Dodge Animal Health; 3-5 mg/kg IM) and xylazine hydrochloride (2.5 to 3.3 $\mathrm{mg} / \mathrm{kg}$ IM) and euthanized with pentobarbital solution (90-150 mg/kg intravenously 
TABLE 1. Results of vaccine efficacy trial for chronic wasting disease in mule deer (Odocoileus hemionus) in Colorado, USA, 2007. Number of biopsy-positive mule deer over total sampled per group, their identification numbers, and the cumulative proportion infected at each time point after exposure to a PrP $\mathrm{P}^{\mathrm{CWD}}$ contaminated pen.

\begin{tabular}{|c|c|c|c|c|c|c|}
\hline \multirow[b]{2}{*}{$\begin{array}{c}\text { Time } \\
\text { postexposure }(\mathrm{mos})\end{array}$} & \multicolumn{3}{|c|}{ Vaccinates } & \multicolumn{3}{|c|}{ Controls } \\
\hline & $\begin{array}{l}\text { No. positive/ } \\
\text { total sampled }\end{array}$ & ID No. & $\begin{array}{l}\text { Proportion } \\
\text { infected }\end{array}$ & $\begin{array}{l}\text { No. positive/ } \\
\text { total sampled }\end{array}$ & ID No. & $\begin{array}{c}\text { Proportion } \\
\text { infected }\end{array}$ \\
\hline 9 & $3 / 7$ & $1 \mathrm{NV}, 2 \mathrm{KY}, 27$ & 0.43 & $1 / 6$ & 26 & 0.17 \\
\hline 15 & $0 / 4$ & & 0.43 & $2 / 5^{\mathrm{a}}$ & $\mathrm{O}, \mathrm{H}$ & $0.5^{\mathrm{a}}$ \\
\hline 21 & $4 / 4$ & $\begin{array}{l}\text { 1BI, } 1 \mathrm{BR}, \\
1 \mathrm{NE}, 34\end{array}$ & 1.0 & $2 / 2$ & $2 \mathrm{BI}, 22 \mathrm{~S}$ & $0.83^{\mathrm{a}}$ \\
\hline
\end{tabular}

${ }^{\text {a }}$ One control died 13 months postexposure and was negative at that time.

[IV]) or potassium chloride $(400-1000 \mathrm{mEq}$ IV). As the IACUC-determined study endpoint was disease status, and for humane reasons, we did not allow progression to clinical disease once we determined an animal biopsy positive. Necropsy was performed and tissues were collected for histologic examination: parotid, mandibular, retropharyngeal, mesenteric, ileocecocolic, abomasal, ruminal, hepatic, popliteal, prescapular, and internal iliac lymph nodes; nictitans; palatine tonsil; laryngeal tonsil; obex; brain; lung; heart; liver; kidney; spleen; bone marrow; spinal cord; muscle; Peyer's patches; ovary; uterus; and cervix.

Genetic analysis indicated all animals were wild type (SS) at codon 225. Genotypic variation at codon 225 may influence the progression of CWD in mule deer. Deer expressing polymorphism SF experience decreased disease progression as compared to those expressing SS (Jewell et al., 2005; Fox et al., 2006). Because the deer were all SS, it is unlikely that the study outcome was influenced by genetic variation; however, the contribution of other genes and PrP-flanking regions to disease susceptibility or resistance is not completely understood and these cannot be ruled out as factors in the efficacy of the vaccine. We also do not know how SF deer might have responded to this vaccine.

Infection rates and cumulative proportion infected over time were compared between treatment groups using one-sided
Fisher exact test performed in WinPepi (Abramson, 2011). Statistical priority was placed on minimizing chance of type II error in the face of small sample size. Therefore, statistical significance was considered at $P \leq 0.1$. By 21 mo postexposure 12 deer showed evidence of prion infection regardless of vaccine status (Table 1 ). One control died 13 mo postexposure and was negative. All lymphoid tissues and sections of brain were positive for $\mathrm{PrP}^{\mathrm{CWD}}$. Significant differences in overall infection rates and cumulative proportion infected over time were not detected between treatment groups (one-sided Fisher exact $P \geq 0.32$; Table 1 ).

Vaccinates produced an antibody response to both peptide-conjugate vaccines 5 wk postprime vaccination (Fig. 1). The vaccine containing peptide 6 appeared to generate a stronger immune response; however, the immune response was transient, as an immediate decrease in absorbance was seen 3 mo postchallenge and no detectable signal observed after approximately 1 yr postboost (data not shown). No apparent relationship between ELISA absorbance and CWD detection was observed, as animals with high and low ELISA absorbance were CWD positive at the first and last time points (Table 1; Fig. 1).

Intramuscular administration of the two peptide-BCP conjugate vaccines formulated in Adjuvac did not prevent development of lesions associated with CWD in 

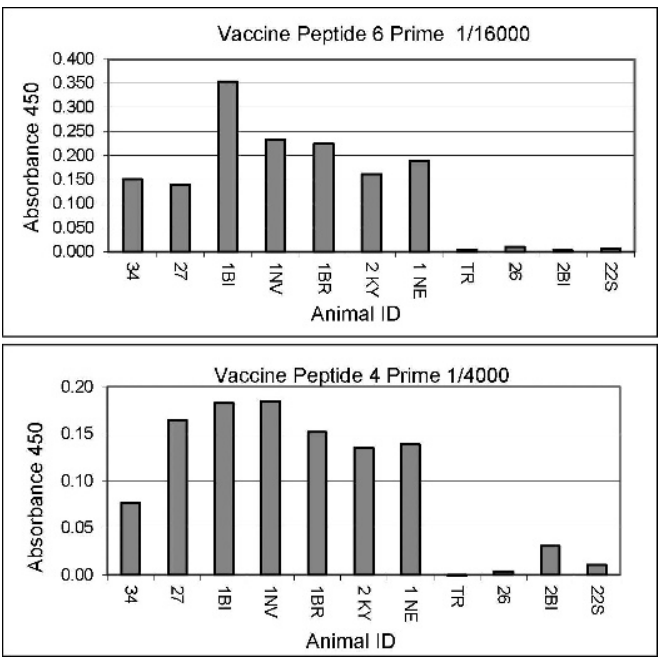

Figure 1. Humoral immune responses in mule deer (Odocoileus hemionus), as measured by enzyme-linked immunosorbent assay to intramuscular vaccination with $3 \mathrm{mg}$ each of cervid prion peptide sequences 168-VDQYNNQNTFVHDC-182 and 145-NDYEDRYYRENMYRYPNQ-164 conjugated to blue carrier protein and administered with Adjuvac. Responses to both peptides were measured 5 weeks postprime vaccination. Seven vaccinates are represented: Animal identification (ID) 34, 27 1BI, $1 \mathrm{NV}, 1 \mathrm{BR}, 2 \mathrm{KY}$, and $1 \mathrm{NE}$. Four control deer are represented: Animal ID TR, 26, 2BI, and 22S.

mule deer naturally exposed to $\mathrm{PrP}^{\mathrm{CWD}}$ at this dosage level. The amount of total antigen delivered to the deer was approximately 20 times lower relative to the original mouse study and was chosen based on our development of this vaccine system (Miller et al., 1997, 2000, 2008a). In previous studies, adequate antibody responses and vaccine effect were produced with lower antigen loads in deer as compared to rodents. Additionally, there is concern regarding autoimmune reactions with high self-antigen loads. At this dosing level, our vaccine combination may not have elicited a sufficient antibody response needed to achieve clinical effect. No clinical signs indicating autoimmune reaction were observed, suggesting higher antigen concentrations or increased dosing may be used without adverse events.

The lack of vaccine protection we observed may be due to inadequate antigen load; however, route of vaccination, species-specific immunologic differences, method of disease challenge, or combinations thereof cannot be ruled out. Our findings emphasize the importance of continuing the search for a vaccine candidate using the target species model in a natural challenge environment.

We acknowledge the following individuals for their valuable time and assistance with this work: Tracy Sirochman, Michael Sirochman, Karl Held, Mike Lavelle, Justin Fischer, Seth Nienhauser, Richanne Lomkin, and Tara Rigg, and other volunteers and seasonal assistants. This work was supported by the USDA/APHIS Science Fellow program and the Colorado Division of Parks and Wildlife.

\section{LITERATURE CITED}

Abramson JH. 2011. WINPEPI updated: Computer programs for epidemiologists, and their teaching potential. Epidemiol Perspect Innov 8:1.

Fox KA, Jewell JE, Williams ES, Miller MW. 2006. Patterns of PrPCWD accumulation during the course of chronic wasting disease infection in orally inoculated mule deer (Odocoileus hemionus). J Gen Virol 87:3451-3461.

Jewell JE, Conner MM, Wolfe LL, Miller MW, Williams ES. 2005. Low frequency of PrP genotype $225 \mathrm{SF}$ among free-ranging mule deer (Odocoileus hemionus) with chronic wasting disease. J Gen Virol 86:2127-2134.

Miller LA, Johns BE, Elias DJ, Crane KA. 1997. Comparative efficacy of two immunocontraceptive vaccines. Vaccine 15:1858-1862.

Miller LA, Johns BE, Killian GJ. 2000. Immunocontraception of white-tailed deer with GnRH vaccine. Am J Reprod Immunol 44:266-274.

Miller LA, Gionfriddo JP, Fagerstone KA, Rhyan JC, Killian GJ. 2008a. The single-shot GnRH immunocontraceptive vaccine (GonaCon TM) in white-tailed deer: Comparison of several GnRH preparations. Am J Reprod Immunol 60:214-223.

Miller MW, Swanson HM, Wolfe LL, Quartarone FG, Huwer SL, Southwick CH, Lukacs PM. 2008b. Lions and prions and deer demise. PLoS ONE 3:e4019.

Miller MW, Wolfe LL, Sirochman TM, Sirochman MA, Jewell JE, Williams ES. 2012. Survival patterns in white-tailed and mule deer after oral inoculation with a standardized, conspecific prion dose. J Wildl Dis 48:526-529.

Pilon J, Loiacono C, Okeson D, Lund S, Vercauteren K, Rhyan J, Miller L. 2007. Anti-prion activity 
generated by a novel vaccine formulation. Neurosci Lett 429:161-164.

Spraker TR, O’rourke KI, Balachandran A, Zink RR, Cummings BA, Miller MW, Powers BE. 2002. Validation of monoclonal antibody F99/97.6.1 for immunohistochemical staining of brain and tonsil in mule deer (Odocoileus hemionus) with chronic wasting disease. J Vet Diagn Investig $14: 3-7$.

Spraker TR, Gidlewski TL, Balachandran A, Vercauteren KC, Creekmore L, Munger RD. 2006. Detection of PrPCWD in postmortem rectal lymphoid tissues in Rocky Mountain elk (Cervus elaphus nelsoni) infected with chronic wasting disease. J Vet Diagn Investig 18:553-557.

Spraker TR, Vercauteren KC, Gidlewski T, Schneider DA, Munger R, Balachandran A, O'Rourke KI. 2009. Antemortem detection of PrPCWD in preclinical, ranch-raised Rocky Mountain Elk
(Cervus elaphus nelsoni) by biopsy of the rectal mucosa. J Vet Diagn Investig 21:15-24.

Williams ES, Young S. 1980. Chronic wasting disease of captive mule deer: A spongiform encephalopathy. J Wildl Dis 16:89-98.

Wolfe LL, Conner MM, Baker TH, Dreitz VJ, Burnham KP, Williams ES, Hobbs NT, Miller MW. 2002. Evaluation of antemortem sampling to estimate chronic wasting disease prevalence in free-ranging mule deer. J Wildl Manag 66:564573.

Wolfe LL, Spraker TR, Gonzalez L, Dagleish MP, Sirochman TM, Brown JC, Jeffrey M, Miller MW. 2007. PrPCWD in rectal lymphoid tissue of deer (Odocoileus spp.). J Gen Virol 88:20782082.

Submitted for publication 25 July 2012

Accepted 7 February 2013. 